\title{
INTERACTION BETWEEN CASEINATE AND CARRAGEENANS RESULTS IN DIFFERENT PHYSICAL AND MECHANICAL PROPERTIES OF EDIBLE FILMS
}

\author{
- Research paper - \\ Alfonso TOTOSAUS*1, Reyna GUTIERREZ*, M. Lourdes PÉREZ-CHABELA** \\ * Food Science Lab \& Pilot Plant, Tecnologico Estudios Superiores Ecatepec, Av. \\ Tecnologico esq. Av. Central s/n, Ecatepec 55210, Estado de Mexico, Mexico. \\ ** Biotechnology Department. Universidad Autonoma Metropolitana Iztapapala. Av. San \\ Rafael Atlixco 186, Mexico City 09340, Mexico.
}

\begin{abstract}
Edible films were elaborated with sodium caseinate and different types of carrageenans (iota, kappa or lambda), and glycerol as plasticizer, to determine the different specific interactions between caseinate and carrageenans on physical and mechanical properties via a response surface methodology approach. The different sulphate groups content in the different carrageenans affected differentially edible films properties. The use of lambda carrageenan in edible film formulation resulted in more soluble and permeably film, with a concomitantly both less rigid and more elastic structure. The edible film formulation was optimized to $8.0 \%$ of caseinate, $0.4 \%$ of carrageenan (irrespectively of the type) and $0.3 \%$ of glycerol.
\end{abstract}

Keywords: Edible films; Caseinate; Carrageenans; Response surface methodology; Mechanical properties; Water vapor permeability.

\section{INTRODUCTION}

Edible films will not replace synthetic packaging, but can be conceived as a complement to improve foods functionality, safety, nutrient content, and mechanical properties (delay moisture, gases, oil and solutes migration). The components to elaborate edible films can be classified in three groups: hydrocolloids, lipids and mixtures. Hydrocolloids are proteins, cellulosic derivatives, alginates, pectin, starches, and lipids as waxes or fatty acids. In addition, plasticizer presence is important to reduce intermolecular forces and favor the polymeric chains motility, improving flexibility and extension (BarbosaCánovas, 2012). The functionality of edible films depends on the nature of the different components and on their final composition and structure. The resulting film properties depend on the polymers structure and treatment conditions. In this view, edible films functional properties can be enhanced if proteins and polysaccharides can be obtained by cross-linking either than with chemical methods (Benbettaïeb et al., 2016). Most recent research has focused on composite films to explore the complementary advantages of different components, like proteins and polysaccharides, and their cross-linking interactions (Chiralt et al., 2018). Research is focused on searching the correct combination between materials mixed looking for the most efficient functional properties of polysaccharides, proteins or composites, depending on biopolymers-based properties (Cazón et al., 2017).

Proteins and polysaccharides with polymeric character provide better mechanical properties to edible films (Pérez-Gago, 2012). Polysaccharides are monotonous biopolymers while proteins have a more varied and specific structure that confer a potential functionality; additionally, in general, polysaccharide based films absorbs more water and are more readily disintegrated with poor barrier properties than protein based films (Cuq et al., 1995). Multicomponent edible films consisting of mixture of various polymers, polysaccharides, proteins and/or lipids have been developed to have cooperative functionalities. On one hand,

${ }^{1}$ Corresponding author. Mailing address: atotosaus@tese.edu.mx 
polysaccharides impart structural cohesion serving as structural matrix; on the other hand, proteins give rise to a very firm structure by both inter- or intramolecular folding and interaction (Wu et al., 2002). Caseinate or carrageenan are a widely protein employed in multicomponent edible films (Chevalier et al., 2018; Sadeghi et al., 2018; Dyshlyuk et al., 2017). Carrageenans are widely employed hydrocolloids for edible films formulation as well (Farhan et al., 2017).

Milk proteins are some of the most common source of hydrocolloids used to obtain films and coatings, having a particular interest since they can provide a high nutritional added value and good taste in addition to their barrier and filmogenic properties (Campos et al., 2011). Caseins and caseinates can readily form edible films from aqueous solutions since caseins are quite soluble in water despite their high content of nonpolar amino acids (35- $45 \%$ of total amino acids residues). Due to the structure and amino acid composition of caseins, it is likely that hydrogen bonds, electrostatic interactions and most probably hydrophobic forces are involved in the formation of casein-based edible films (Schou et al., 2005; Frinault et al., 2006).

The polyelectrolyte character of milk proteins in the interaction with hydrocolloids like carrageenan plays an important role in determining mixed biopolymer behavior (Dickinson, 1998). Carrageenans, which are film-formers, are used mainly in the food

\section{MATERIALS AND METHODS}

Edible films elaboration: Edible films were elaborated with sodium caseinate (DVA Mexicana, Naucalpan), glycerol as plasticizer, and Viscarin SD389 iota carrageenan, Viscarin GP209 lambda carrageenan, or Gelcarin GP8612 kappa carrageenan (FMC Biopolymers, Philadelphia). Edible films were prepared by the casting technique, dehydrating the filmogenic protein-carrageenan-plasticizer solution. Sodium caseinate was dissolved in $100 \mathrm{~mL}$ of distilled water, adding glycerol $<1$ and finally the respective carrageenan type. Caseinate (6 to 10 $\%)$, each carrageenan type ( 0.2 to $0.6 \%)$ and glycerol $(0.15$ to $0.45 \%)$ concentrations, determined by previous research, are listed in Table 1, according to the experimental design, in order to establish the effect of carrageenan type on caseinate edible films properties. Solutions were poured in glass plates $(12 \times 12 \mathrm{~cm})$ and industry as texturizing agents with potential use as coating agents that control transfer of moisture, gases, flavors, and lipids in diverse food systems (Soliva-Fortuny et al., 2012). The number and position of sulfate groups entails a negative charge that affects the functionality of the different carrageenan types (Langendorff et al., 2000). The first postulation of the specific active site in kappa-casein was between aminoacid residues 97-112 that interacts electrostatically with carrageenans negative sulphate groups $\kappa$-carrageenan on the alkaline side of the protein isoelectric point (Snoeren et al., 1975). The interaction of carrageenans with caseinate has been studied in many dairy systems, as casein micelles in skim milk (Dalgleish \& MORRIS, 1988; Langendorff et al., 1999), or milk-based fluid systems (Spagnoulo et al., 2005). Carrageenan interaction also has been studied in model systems like sodium caseinate (Keogh et al., 1996), sodium caseinate O/W emulsion (Singh et al., 2003) or with commercial milk proteins (Hemar et al., 2003).

The objective of this work was to determinate the effect of carrageenan, sodium caseinate and glycerol concentrations, for different carrageenans (iota, lambda or kappa), on edible films physicochemical and mechanical properties employing a surface response methodology to optimize formulation.

dried at room temperature $\left(25 \pm 1{ }^{\circ} \mathrm{C}\right)$ at $55 \pm 5 \%$ of relative humidity (RH) during $48 \mathrm{~h}$. Afterward, edible films were kept in desiccators for further analysis.

Total soluble material and soluble protein: Total soluble material was determined according to the method reported by Pereda et al. (2012). Edible films samples $(2 \times 2 \mathrm{~cm})$ were weight and immersed in $30 \mathrm{~mL}$ of water during $24 \mathrm{~h}$. After immersion, samples were oven dried at $105{ }^{\circ} \mathrm{C}$ during $24 \mathrm{~h}$ to determinate the insoluble material. Total soluble material was reported as the percent of dissolved mass (dry basis) with respect to the initial film dry weight.

From the distilled water employed in total soluble material, soluble protein was determined by biuret method (Gornall et al., 1949). Film soluble protein was reported according to Jangchud \& Chinnan (1999), as in Eq. 1. 
Table 1. Central composed design for the sodium caseinate-carrageenan-glycerol edible films elaborated with each one of the different carrageenan type

\begin{tabular}{|c|c|c|c|c|c|c|}
\hline \multirow{2}{*}{ Run } & \multicolumn{2}{|c|}{ Sodium caseinate $\left(\mathrm{X}_{1}\right)$} & \multicolumn{2}{c|}{ Carrageenan $\left(\mathrm{X}_{2}\right)$} & \multicolumn{2}{c|}{ Glycerol $\left(\mathrm{X}_{3}\right)$} \\
\cline { 2 - 7 } & Coded & $\%(\mathrm{w} / \mathrm{v})$ & Coded & $\%(\mathrm{w} / \mathrm{v})$ & Coded & $\%(\mathrm{w})$ \\
\hline 1 & -1 & 6.0 & -1 & 0.2 & 0 & 0.3 \\
\hline 2 & -1 & 6.0 & 1 & 0.6 & 0 & 0.3 \\
\hline 3 & 1 & 10.0 & -1 & 0.2 & 0 & 0.3 \\
\hline 4 & 1 & 10.0 & 1 & 0.6 & 0 & 0.3 \\
\hline 5 & 0 & 8.0 & -1 & 0.2 & -1 & 0.15 \\
\hline 6 & 0 & 8.0 & -1 & 0.2 & 1 & 0.45 \\
\hline 7 & 0 & 8.0 & 1 & 0.6 & -1 & 0.15 \\
\hline 8 & 0 & 8.0 & 1 & 0.6 & 1 & 0.45 \\
\hline 9 & -1 & 6.0 & 0 & 0.4 & -1 & 0.15 \\
\hline 10 & 1 & 10.0 & 0 & 0.4 & -1 & 0.15 \\
\hline 11 & -1 & 6.0 & 0 & 0.4 & 1 & 0.45 \\
\hline 12 & 1 & 10.0 & 0 & 0.4 & 1 & 0.45 \\
\hline 13 & 0 & 8.0 & 0 & 0.4 & 0 & 0.3 \\
\hline 14 & 0 & 8.0 & 0 & 0.4 & 0 & 0.3 \\
\hline 15 & 0 & 8.0 & 0 & 0.4 & 0 & 0.3 \\
\hline
\end{tabular}

Soluble protein $(\%)=\frac{\text { Protein concentration in } 30 \mathrm{~mL}}{\text { Initial film weight } \times \% \text { protein in film } \times \% \text { film dry matter }}$

Water vapor permeability: Water vapor permeability was calculated adapting the methodology reported by Jangchud \& Chinnan (1999). Film samples were placed and fixed at the top of glass flasks $\left(13.854 \mathrm{~cm}^{2}\right.$ total exposed area) containing distilled water $(100 \% \mathrm{RH})$. Flasks were weighted 7 to 10 times during a $6 \mathrm{~h}$ period at room temperature $\left(25^{\circ} \mathrm{C}\right)$ and $50 \pm 5$ $\mathrm{RH}$. Change in weight due to water vapor loss trough film was calculated as the slope of weight vs. time curve (linear regression). Water vapor permeability was calculated as:

WVP $(\mathrm{g} / \mathrm{Pa} \mathrm{s} \mathrm{m})=\frac{\mathrm{WVPR} \times \mathrm{L}}{\Delta \mathrm{p}}$

where WVPR is the water vapor permeability rate (calculated as slope of water vapor loss multiplied by the exposed area), $\mathrm{L}$ is the average film thickness, and $\Delta \mathrm{p}$ is the vapor pressure difference across the film (calculated based on the temperature and $\mathrm{RH}$ inside and outside the flask). Film thickness was determined as the average of at least 5 random locations measure employing a Mitutoyo IP 65 digital micrometer (Mitutoyo, Tokyo).

Film opacity: Film samples were placed on an acrylic cell without front and back walls. Samples were scanned from 400 to $800 \mathrm{~nm}$ in a Genesys 10 spectrophotometer (Thermo Fisher Scientific, Pittsburg), reporting film opacity as the area under the curve divided by average film thickness (Pereda et al., 2012).

Puncture force and deformation: Force and deformation at the breaking point was determined according to the_methodology described by Sobral et al. (2001). Samples were fixed in $52.4 \mathrm{~mm}$ diameter acrylic cells and perforated in the center with a $3 \mathrm{~mm}$ aluminum probe at a constant rate of one $\mathrm{mm} / \mathrm{s}$ in a LFRA 4500 texturometer (Brookfield Engineering Laboratories, Middleboro). From time-force curves, puncture force (maximum force at film breakdown) was reported and puncture deformation was calculated as:

Puncture deformation $(\%)=\frac{\sqrt{\left(\mathrm{D}^{2}+1_{0}^{2}\right)}-1_{0}}{1_{0}} \times 100$

Considering that the stress was perfectly distributed along the film, where $\mathrm{D}$ is probe displacement, $1_{0}$ is the initial film length (radius of the measurement cell, $26.2 \mathrm{~mm}$ ).

Tensile strength and elongation: Film tensile strength and elongation percent were determined employing a Chatillon TCM 200 motorized test stand equipped with a Chatillon DFIS 200 digital force gauge (Ametek, Largo) according to the methodology_described by Gennadios et al. (1993). Films samples were cut in $100 \times 25.4$ $\mathrm{mm}$ and placed in the grips with an initial separation of $50 \mathrm{~mm}$. Samples were stretched at a constant speed rate of $1 \mathrm{~mm} / \mathrm{s}$ until breakdown. Tensile strength was calculated dividing the peak load by the cross sectional area (film width $\times$ thickness). The elongation percent was calculated as the ratio of the extension values and the initial grip separation multiplied by 100 .

Experimental design and data analysis: To determinate the effect of the percent of caseinate, the percent and type of carrageenan, and the percent of plasticizer on edible films 
properties, a response surface methodology was employed. A rotatable central composite design was proposed for optimization of caseinatecarrageenan edible film formulation at five levels with 20 runs (15 runs and five replicates of central point) (Table 1) (Montgomery \& Runger, 2003). The experimental results were analyzed in SAS software v. 8.0 ADX interface (SAS Institute, Cary), fitting second order model to establish relationship between independent variables (the respective concentrations of sodium caseinate $\mathrm{X}_{1}$, carrageenan $\mathrm{X}_{2}$ and glycerol $\mathrm{X}_{3}$ ) with response variables $\mathrm{Y}$, as follows:

$\mathrm{Y}=\beta_{0}+\sum_{1} \beta_{1} \mathrm{X}_{1}+\sum_{2} \beta_{2} \mathrm{X}_{2}+\sum_{3} \beta_{3} \mathrm{X}_{3}+\sum \beta_{13} \mathrm{X}_{1} \mathrm{X}_{3}+\epsilon$

where $Y$ is the response variable that corresponds to edible films physicochemical and mechanical properties, $\beta_{0}, \beta_{1}, \beta_{2}$, and $\beta_{3}$ are the estimate linear regression coefficients for caseinate concentration, carrageenan concentration, and glycerol concentrations, respectively. $\beta_{13}$ is the interaction parameter for caseinatexcarrageenan effect and $\epsilon$ is the experimental error. Response contour plots were generated in the same software holding one variable constant $($ glycerol $=0.45 \%$ ), for each carrageenan type.

\section{RESULTS AND DISCUSSION}

Total soluble material and soluble protein For edible films with iota-carrageenan, total soluble material was highly significant $(\mathrm{P}>$ 0.0001 ) affected by the proportion of the ingredients $\left(\mathrm{R}^{2}=0.8814\right)$. According to ANOVA, carrageenan linear parameter and the iota-carrageenan $\times$ caseinate interaction presented a significantly ( $>>0.05)$ effect. For kappacarrageenan containing film formulations, total soluble material was significantly $(\mathrm{P}=0.7223)$ affected by the ingredients proportions $\left(\mathrm{R}^{2}=\right.$ 0.7571). According to ANOVA, linear term for caseinate parameter presented a significantly $(\mathrm{P}>$ 0.05) effect, as well as the kappacarrageenan $\times$ caseinate interaction. In edible films with lambda-carrageenan, total soluble material was significantly $(\mathrm{P}=0.0271)$ affected by the ingredients proportion $\left(\mathrm{R}^{2}=0.5561\right)$. According to ANOVA, linear term parameters and the carrageenan $\times$ caseinate interaction presented a significantly $(\mathrm{P}>0.05)$ effect. At higher caseinate proportions the edible films' soluble material decreased, this is, more caseinate resulted in lower soluble film material. The dissolved material of edible film increased at higher carrageenan concentrations. In the interaction caseinatexcarrageenan, the lower total soluble material values were observed at higher proportions of both ingredients. It seems that glycerol increased the total soluble material since in the regression equation, for all the
Selected multiple responses in the central composite design were maximized or minimized, according to desirable characteristics for edible film (higher total soluble material, lower opacity, higher puncture resistance and higher elongation) in order to obtain the optimization of edible films formulation, in the Desirability function of the Prediction profiler in same SAS ADX interface, where according to SAS support the overall desirability can be defined as the geometric mean of the desirability for each response.

carrageenan types, having a positive sign. Total soluble material of edible films made with lambda carrageenan was the lower one, as compared to kappa or iota carrageenan containing edible films.

In Figure 1a it can be appreciated that the higher sulphate groups content the lower total soluble material (this is, lambda $<$ kappa $<$ iota), suggesting a strong interaction between the sulphate groups and the positively charged regions in caseinate increased the dissolve of edible films. The carrageenan type effect in total soluble mater seems to be linked to the number of sulphate groups.

Soluble protein in edible films containing iota carrageenan, soluble protein was highly significant $(\mathrm{P}>0.0001)$ affected by the ingredients concentrations $\left(\mathrm{R}^{2}=0.8702\right)$. According to ANOVA, all the linear terms parameters and caseinate $\times$ carrageenan interaction parameter presented a significantly $(\mathrm{P}>0.05)$ effect. For edible films with kappa carrageenan, soluble protein was highly significant $(\mathrm{P}>0.0001)$ affected by ingredients concentrations $\left(\mathrm{R}^{2}=0.8105\right)$. According to ANOVA, linear parameters and caseinate $\times$ carrageenan interaction presented a significantly ( $>>0.05)$ effect. For lambda carrageenan edible films, soluble protein was highly significant $(\mathrm{P}=0.0075)$ affected by formulation $\left(\mathrm{R}^{2}=0.6224\right)$. According to 
ANOVA, caseinate and glycerol linear terms parameters and caseinate $\times$ carrageenan interaction parameter presented a significantly $(\mathrm{P}>0.05)$ effect. In soluble protein, at higher carrageenan proportions the soluble protein decreased.

Contour plots in Figure $1 \mathrm{~b}$ shown that for the carrageenan type, lambda carrageenan with more sulphate groups resulted in higher soluble protein released from edible films. At higher proportions of caseinate the soluble protein increased as well, this is, more protein concentration resulted in higher soluble protein from edible films. For the caseinate $\times$ carrageenan interaction, soluble protein decreased at higher concentrations of both components, except for lambda carrageenan edible films. Glycerol had a negative sign in the equation regression, indicating that more glycerol decreased soluble protein.

Edible caseinate films with lambda-carrageenan presented higher soluble matter, releasing more protein in solution. This can be due to the differences between the interaction behavior and the charge density attributed to the different carrageenan conformation (Gu et al., 2005). All three forms of carrageenan adsorb to casein micelles at temperatures below the coil-helix transition of $60{ }^{\circ} \mathrm{C}$ (Dalgleish \& Morris, 1998). Nonetheless, kappa-carrageenan and iotacarrageenan undergo a temperature-dependent coil (disordered state) to helix (ordered state) transition in aqueous solution (Cěrníková et al., 2008), and at room temperature, kappa- and iotacarrageenan are in the helix form, whereas lambda-carrageenan is in the random coil form (Nilsson \& Piculell, 1989; Corredig et al., 2011). Caseins interactions are stronger when the carrageenan in the helical conformation (Langendroff et al., 2000; Gu et al., 2005), and since kappa and iota-carrageenan are the helical conformation at the experimental condition employed during edible film casting, the stronger interaction decreased both soluble material and soluble protein. (a)

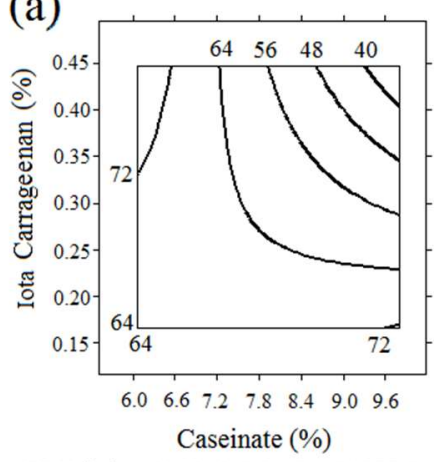

$\operatorname{TSM}(\%)=62.08-8.71 \mathrm{CAS}+7.98 \mathrm{GLY}$ -6.24CAR -13.13CASXCAR

(b)
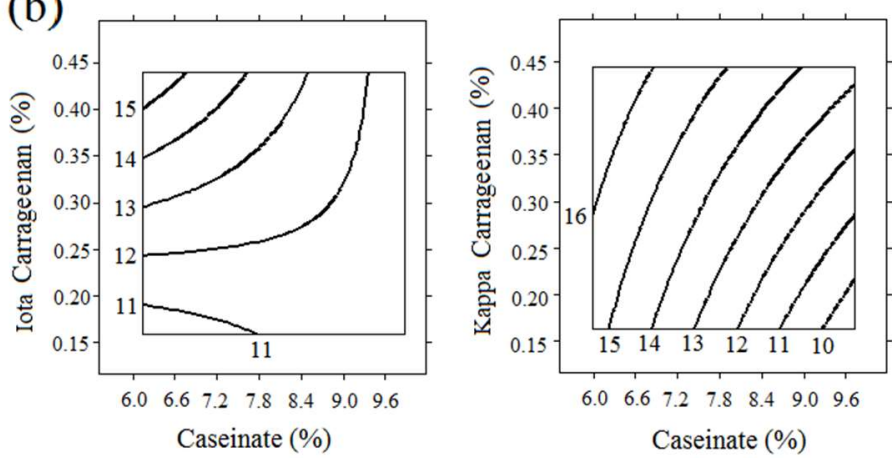

SOL PROT $(\%)=12.32-0.74 \mathrm{CAS}-3.98 \mathrm{GLY}$

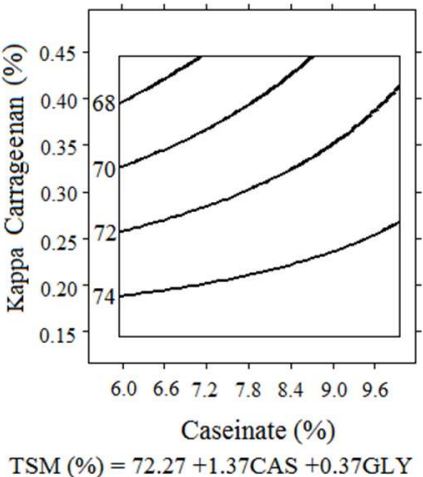

$\operatorname{TSM}(\%)=72.27+1.37 \mathrm{CAS}+0.37 \mathrm{GLY}$

$-3.23 \mathrm{CAR}+1.16 \mathrm{CASXCAR}$
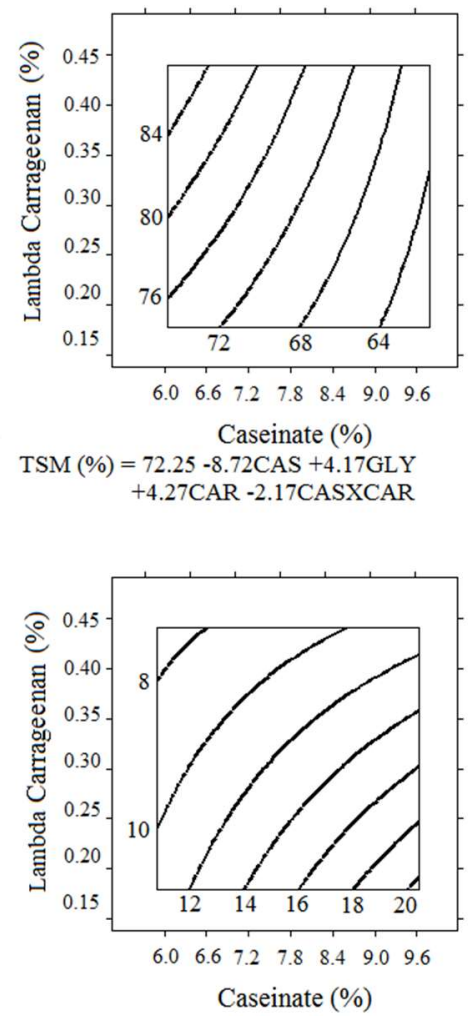

Figure 1. Contour plot and adjusted regression equation for (a) total soluble material (TSM) and (b) soluble protein (SOL PROT) for the sodium caseinate edible films elaborated with the different carrageenan type (CAS: caseinate, CAR: carrageenan, GLY: glycerol). Glycerol fixed level $=0.45 \%$. 


\section{Water vapor permeability}

In edible films with iota carrageenan, water vapor permeability was highly significant $(\mathrm{P}=$ 0.0015) affected by the components concentrations at the experimental conditions in this research $\left(\mathrm{R}^{2}=0.6877\right)$. According to ANOVA, linear terms parameters for caseinate and carrageenan and caseinate $\times$ carrageenan interaction were significantly $(\mathrm{P}>0.05)$, but glycerol presented no significantly $(\mathrm{P}<0.05)$ effect. For kappa carrageenan edible films, the different components percentages had a highly significant effect $(\mathrm{P}=0.0008)$ on this property $\left(\mathrm{R}^{2}=0.7083\right)$. According to ANOVA, all the equation parameters (linear terms and interaction) presented a significantly $(\mathrm{P}>0.05)$ effect. For formulations with lambda carrageenan, there was a highly significantly effect $(\mathrm{P}>0.0001)$ on the edible films water vapor permeability $\left(\mathrm{R}^{2}=0.8846\right)$. According to ANOVA, linear terms and the carrageenan $\times$ caseinate interaction presented a significantly (P> 0.05) effect. At higher carrageenan concentration, the films water vapor permeability decreased. Same behavior was observed for caseinate, and for the caseinate $\times$ carrageenan interaction, where higher proportion of both components decreased the film permeability. Glycerol had a positive sign in the regression equation.

In the Fig. 2a, the different contour plots for water vapor permeability presented higher values for the lambda carrageenan edible films, due to the more sulphate content in lambda carrageenan, whereas iota carrageenan with only one sulphate groups resulted in the lower water vapor permeability values. It seems that more sulphate groups of lambda carrageenan interactions with caseinate proteins resulted in a more permeable to water vapor material.

In protein-polysaccharide mixtures, the ratio of protein and polysaccharide influence the charge balance of the formed complexes, where the excess in one of the components (protein or polysaccharide) resulted in soluble complexes formation, because of the presence of nonneutralized charges, besides the competition for the solvent (Ye, 2008). This strong interaction explains how at the experimental conditions the water vapor permeability increased due to interaction between carrageenans and caseinate during the edible film casting. Edible films containing lambda carrageenan increased water vapor permeability of the films due the caseinate- $\lambda$-carrageenan matrix structure formation (Fabra et al., 2008). Conformation of carrageenans at the experimental conditions employed resulted in a strong interaction of iota and kappa carrageenan, as compared to lambda, decreasing edible film solubility, with concomitantly lower water vapor permeability.

\section{Opacity}

For formulations with iota carrageenan, there was a highly significantly $(\mathrm{P}>0.0001)$ effect on the edible films opacity $\left(\mathrm{R}^{2}=0.8535\right)$. According to ANOVA, glycerol linear terms and caseinate $\times$ carrageenan interaction presented a significantly $(\mathrm{P}>0.05)$ effect. In edible films with kappa carrageenan, there was a highly significantly $(\mathrm{P}>0.0001)$ effect on opacity $\left(\mathrm{R}^{2}=\right.$ 0.9197). According to ANOVA, linear terms parameters and caseinate $\times$ carrageenan interaction parameter presented a significantly $(\mathrm{P}>0.05)$ effect. In lambda carrageenan formulations, there was a highly significantly ( $P>0.0001)$ effect on the edible films opacity $\left(\mathrm{R}^{2}=0.7735\right)$. According to ANOVA, both caseinate and carrageenan linear terms and caseinate $\times$ carrageenan interaction presented a significantly $(\mathrm{P}>0.05)$ effect.

In contours plots (Figure 2b) for the films opacity, it was observed that at higher carrageenan and caseinate concentrations increased films opacity, where the caseinatexcarrageenan interaction resulted as well in higher opacity values. The average film thickness was $78 \pm 5,77 \pm 6$ and $75 \pm 3 \mu \mathrm{m}$, for iota, kappa and lambda carrageenan, respectively. Opacity was derived from the components interactions, where more sulphate groups content in lambda carrageenan resulted in lower opacity values.

Edible films transparency is determined the absorption spectrum in the visible range, and low absorption curve value is related to lower opacity (Zaritzky, 2011). At the experimental conditions in this research, both higher solubility and water vapor permeability in lambda carrageenan containing edible films were more transparent. In same manner, glycerol content did not affect the thickness of sodium caseinate edible films (Schou et al., 2005).

\section{Puncture force and deformation}

For edible films with iota carrageenan, puncture force was highly significant $(\mathrm{P}>0.0001)$ affected by the proportion of the ingredients $\left(\mathrm{R}^{2}=\right.$ 0.8600). According to ANOVA, only caseinate linear parameter presented a significantly $(\mathrm{P}>0.05)$ effect. For kappa carrageenan containing film formulations, puncture force was 
highly significant $(\mathrm{P}>0.0001)$ affected by the ingredients proportions $\left(\mathrm{R}^{2}=0.9402\right)$. According to ANOVA, linear terms parameters presented a significantly $(\mathrm{P}>0.05)$ effect. In edible films with lambda carrageenan, puncture force was highly significant $(\mathrm{P}>0.0001)$ affected by the ingredients proportion $\left(\mathrm{R}^{2}=0.8154\right)$. According to ANOVA, only caseinate linear parameter presented a significantly $(\mathrm{P}>0.05)$ effect.

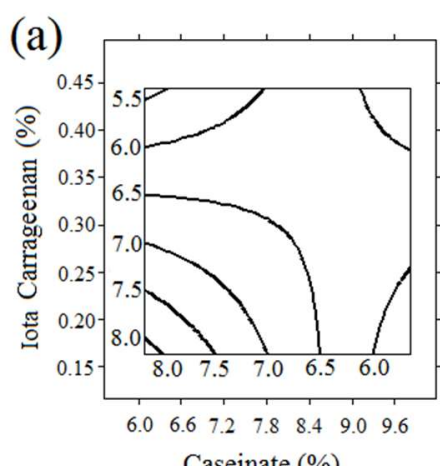

WVP $(\mathrm{g} / \mathrm{Pa} \mathrm{s} \mathrm{m})=6.49-0.29 \mathrm{CAS}+0.78 \mathrm{GLY}$ $-0.42 \mathrm{CAR}+0.98 \mathrm{CASXCAR}$

(b)

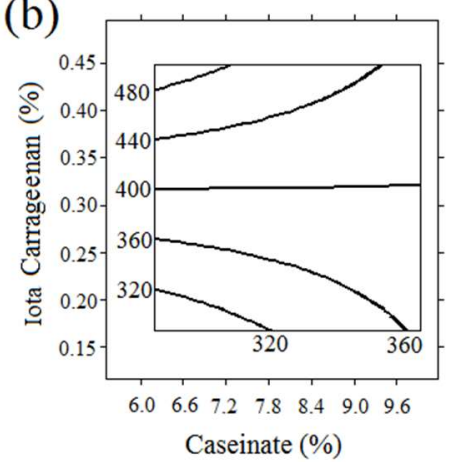
OPACITY $(\mathrm{Abs} / \mathrm{mm})=405+2 \mathrm{CAS}+28 \mathrm{GLY}$
$+70 \mathrm{CAR}+38 \mathrm{CAS} \times \mathrm{CAR}$

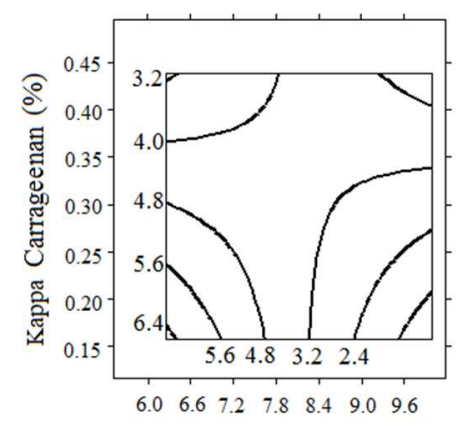

Caseinate (\%)

WVP $(\mathrm{g} / \mathrm{Pa} \mathrm{s} \mathrm{m})=5.43+0.68 \mathrm{CAS}+0.26 \mathrm{GLY}$ $+0.01 \mathrm{CAR}-1.75 \mathrm{CASXCAR}$

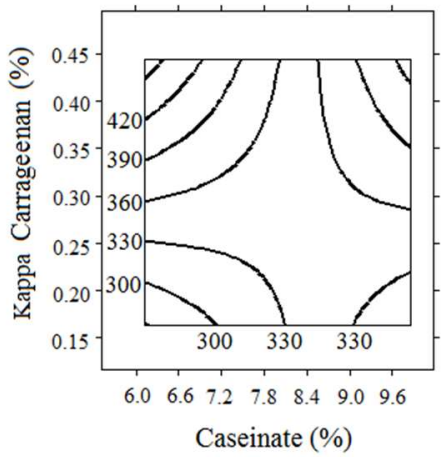

OPACITY $(\mathrm{Abs} / \mathrm{mm})=406+22 \mathrm{CAS}+14 \mathrm{GLY}$ OPACITY $(\mathrm{Abs} / \mathrm{mm})=339+9.8 \mathrm{CAS}+9.4 \mathrm{GLY}$ $+17 \mathrm{CAR}+82 \mathrm{CAS} \times \mathrm{CAR}$
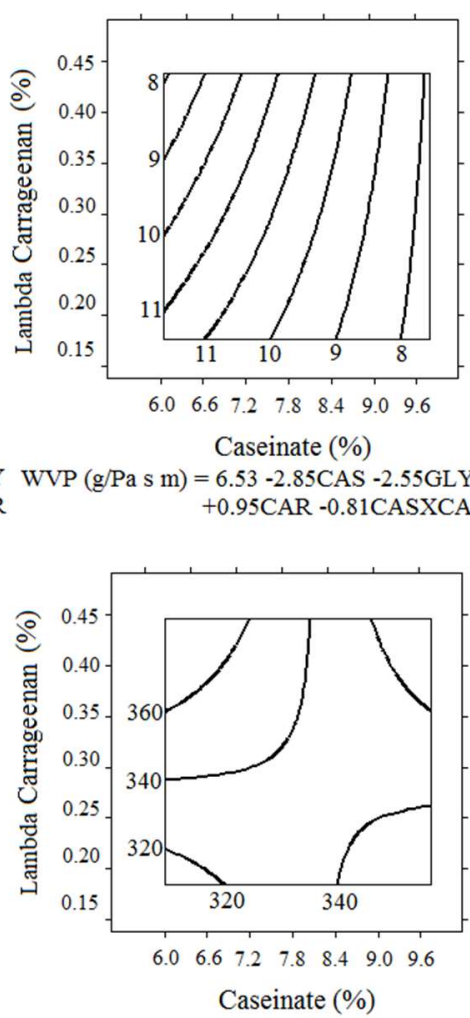

Caseinate (\%)

$=6.53-2.85 \mathrm{CAS}-2.55 \mathrm{GLY}$ +0.95 CAR -0.81 CASXCAR $+5.4 \mathrm{CAR}+34 \mathrm{CAS} \times \mathrm{CAR}$

Figure 2. Contour plot and adjusted regression equation for (a) water vapor permeability (WVP, $\mathrm{g} \mathrm{mm} / \mathrm{pa} \mathrm{m}^{2}$ $\mathrm{h} \times 10^{4}$ ) and (b) opacity for the sodium caseinate edible films elaborated with the different carrageenan type (CAS: caseinate, CAR: carrageenan, GLY: glycerol). Glycerol fixed level $=0.45 \%$.

The increase in carrageenan concentration increased the force necessary to rupture the edible films, as can be observed in the different contours plots for each carrageenan type (Figure 3a). In same manner, higher caseinate proportions increased as well as the puncture force. For the caseinatexcarrageenan interaction, higher puncture force was observed at higher concentrations of both components, where at higher carrageenan concentrations the detected force decreased. Higher puncture force values were observed in the iota carrageenan edible films, and the lower ones in the lambda carrageenan samples. Glycerol concentration affected puncture force (negative sign in regression equation), where higher glycerol concentration decreased force values.

In edible films with iota carrageenan, puncture deformation was highly significant $(\mathrm{P}=0.0044)$ affected by the components concentrations at the experimental conditions employed $\left(\mathrm{R}^{2}=0.6462\right)$. According to ANOVA, linear terms parameters for caseinate and carrageenan were significantly $(\mathrm{P}>0.05)$, and no significantly $(\mathrm{P}<0.05)$ effect was observed for glycerol. For kappa carrageenan edible films, the different components percentages had a highly significant effect $(\mathrm{P}>0.0001)$ on puncture deformation $\left(\mathrm{R}^{2}=\right.$ 0.9251). According to ANOVA, only linear equation parameters presented a significantly $(\mathrm{P}>0.05)$ effect. For formulations with lambda carrageenan, there was a highly significantly effect $(\mathrm{P}>0.0001)$ on the edible films puncture deformation $\left(\mathrm{R}^{2}=0.9837\right)$. According to ANOVA, linear terms and caseinate $x$ carrageenan interaction presented a significantly $(\mathrm{P}>0.05)$ effect.

In Figore $3 b$, contour plots for the puncture deformation, it can be observed that the increase in both carrageenan and caseinate resulted in 
higher deformation values, where as well as for puncture force, when carrageenan content increased the edible film deformability decreased. Lambda carrageenan presented higher puncture deformation values. Glycerol had a negative effect on puncture deformation as well, and hence higher concentration of plasticizer resulted in stretchable structure.

More solids contents were related with a stronger structure. In same manner, increase in plasticizer concentration had a great influence on caseinate films flexibility (Folegatti et al., 1998). Since iota and kappa carrageenan are non-temperature depend conformation, their interaction with casein resulted in tough but less extendible films. At the experimental conditions, lower interaction during film formation in lambda carrageenan (with three sulphate groups but in the random coil conformation) samples. Lambda carrageenan, with more sulfate groups and higher electric charge density besides the no temperature dependence on it conformation result in stronger attractive interaction with caseins proteins (Langendorff et al., 2000). This interaction between lambda-carrageenans and sodium caseinate contributed to increase the protein particle size giving rise to a more open structure, increasing edible film flexibility and ability to extent (Fabra et al., 2008). (a)

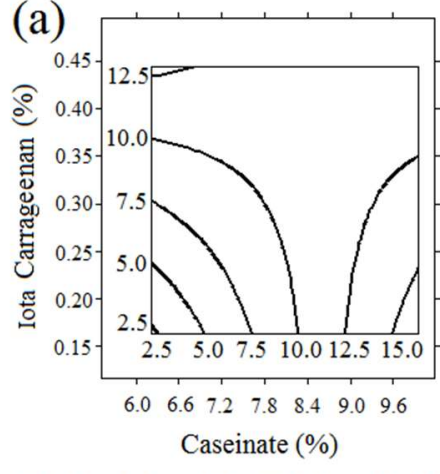

P FORCE $(\mathrm{N})=10.5+3.01 \mathrm{CAS}-4.2 \mathrm{GLY}$ -1.21CAR $-4.2 \mathrm{CAS} \times \mathrm{CAR}$

(b)

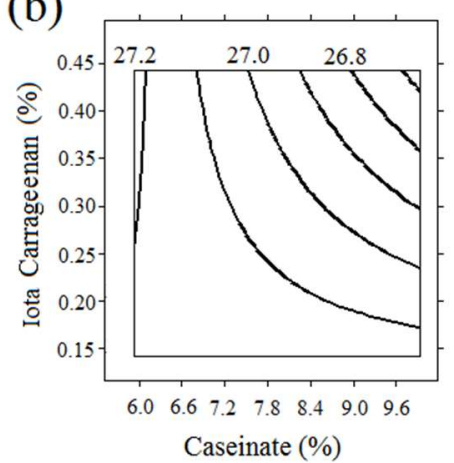

P DEFOR $(\%)=27.08-0.12 \mathrm{CAS}+1.01 \mathrm{GLY}$ $+0.10 \mathrm{CAR}-0.04 \mathrm{CAS} \times \mathrm{CAR}$

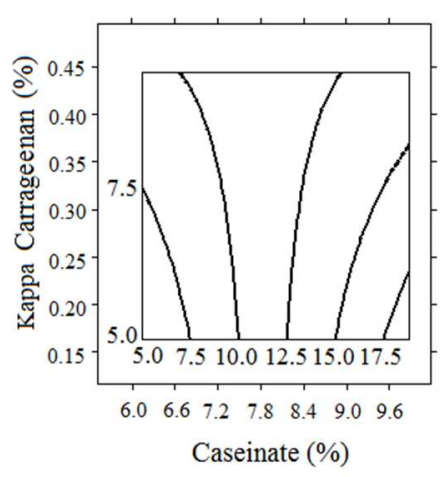

P FORCE $(\mathrm{N})=11.71+4.53 \mathrm{CAS}-1.6 \mathrm{GLY}$ -0.23 CAR -2.45 CAS $\times$ CAR

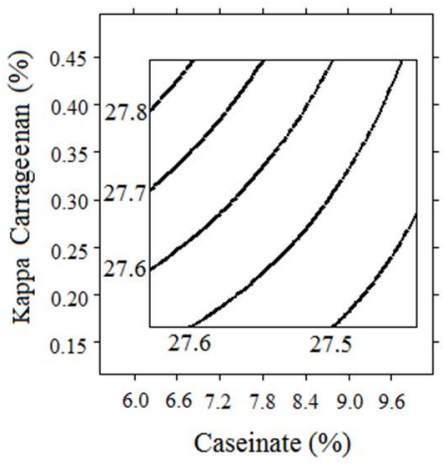
$\begin{aligned} \operatorname{PDEFOR}(\%) & =27.51-0.38 \mathrm{CAS}+1.83 \mathrm{GLY} \\ & +0.54 \mathrm{CAR}-0.49 \mathrm{CAS} \times \mathrm{CAR}\end{aligned}$

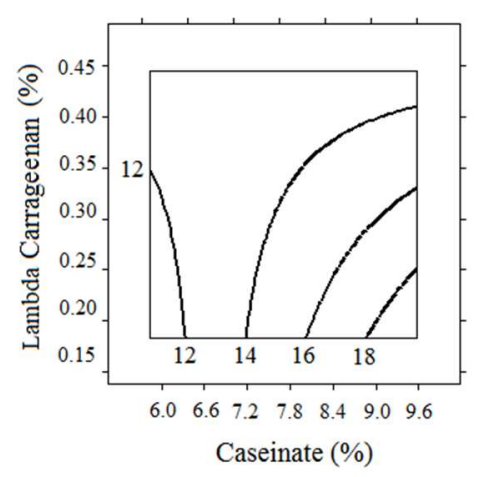

P FORCE $(\mathrm{N})=14.09+2.35 \mathrm{CAS}-6.04 \mathrm{GLY}$ $-1.19 \mathrm{CAR}-2.13 \mathrm{CAS} \times \mathrm{CAR}$

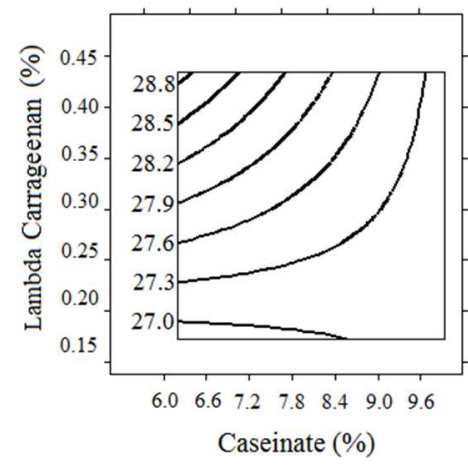

P DEFOR $(\%)=27.64-0.12 \mathrm{CAS}+1.78 \mathrm{GLY}$ $+0.09 \mathrm{CAR}-0.11 \mathrm{CAS} \times \mathrm{CAR}$

Figure 3. Contour plot and adjusted regression equation for (a) puncture force (P FORCE) and (b) puncture deformation (P DEFOR) for the sodium caseinate edible films elaborated with the different carrageenan type (CAS: caseinate, CAR: carrageenan, GLY: glycerol). Glycerol fixed level $=0.45 \%$.

\section{Tensile strength and elongation}

For edible films with iota carrageenan, films tensile strength was highly significant ( $\mathrm{P}>$ 0.0001) affected by the proportion of the ingredients $\left(\mathrm{R}^{2}=0.9234\right)$. According to ANOVA, the linear parameter and the caseinate $\times$ carrageenan interaction presented a significantly ( $\mathrm{P}>0.05)$ effect. For kappa carrageenan containing film formulations, tensile strength was highly significant $(\mathrm{P}>$ $0.0001)$ affected by the ingredients proportions $\left(\mathrm{R}^{2}=0.9128\right)$. According to ANOVA, the linear parameter and the carrageenan $\times$ caseinate interaction presented a significantly $(\mathrm{P}>0.05)$ effect. In edible films with lambda carrageenan, tensile strength was highly significant ( $\mathrm{P}>$ $0.0001)$ affected by the ingredients proportion $\left(\mathrm{R}^{2}=0.8763\right)$. According to ANOVA, only linear 
term parameters for caseinate presented a significantly $(\mathrm{P}>0.05)$ effect.

In Figure 4a, as expected, it can be observed in the different contour plots for each carrageenan type, that the increase in carrageenan concentration resulted in higher tensile strength values, specifically in carrageenans with more sulphate groups' content, lambda. The higher proportions of caseinate also resulted in higher force requited to extend the edible films, except in samples containing iota carrageenan, where at low carrageenan concentration the tensile force remained practically constant.

In edible films with iota carrageenan, elongation was highly significant $(\mathrm{P}=0.0035)$ affected by the components concentrations at the experimental conditions employed $\left(\mathrm{R}^{2}=0.6550\right)$. According to ANOVA, linear terms parameters for caseinate and carrageenan were significantly $(\mathrm{P}>0.05)$, but no significantly $(\mathrm{P}<0.05)$ effect was observed caseinate $\times$ carrageenan cross- product parameter. For kappa carrageenan edible films, the different components percents had a highly significant effect (P> 0.0001) on elongation $\left(R^{2}=0.9310\right)$. According to ANOVA, linear terms parameters for caseinate and carrageenan were significantly $(\mathrm{P}>0.05)$, but no significantly $(\mathrm{P}<0.05)$ effect was observed caseinate $\times$ carrageenan interaction. For formulations with lambda carrageenan, there was a highly significantly effect $(\mathrm{P}>0.0001)$ on the edible films water vapor permeability $\left(\mathrm{R}^{2}=\right.$ 0.9850). According to ANOVA, linear terms for caseinate and glycerol and caseinate $\times$ carrageenan interaction presented a significantly $(\mathrm{P}>0.05)$ effect. Carrageenan was not significantly $(\mathrm{P}<0.05)$. As for tensile strength, the elongation capacity of the edible films was higher when carrageenan concentration was increased. (a)

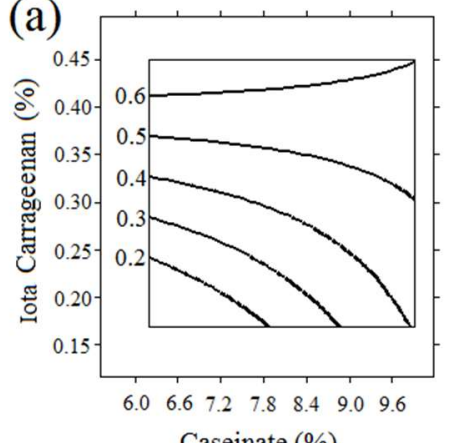

Caseinate $(\%)$

TS $\left(\mathrm{N} / \mathrm{mm}^{2}\right)=0.51+0.17 \mathrm{CAS}-0.17 \mathrm{GLY}$ $-0.06 \mathrm{CAR}+0.09 \mathrm{CASXCAR}$

(b)

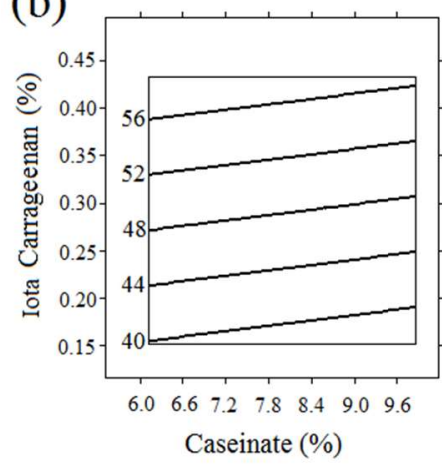

ELONG $(\%)=44.73-0.73 \mathrm{CAS}+2.51 \mathrm{GLY}$

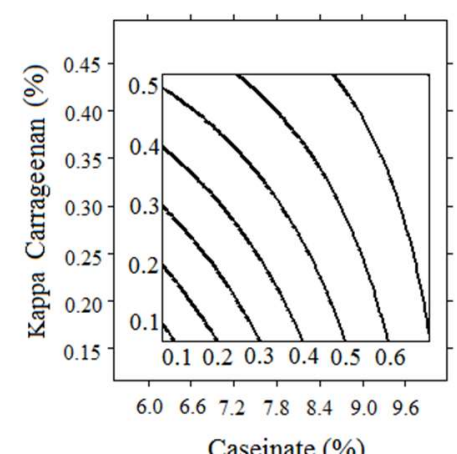

TS $\left(\mathrm{N} / \mathrm{mm}^{2}\right)=0.52+0.23 \mathrm{CAS}-0.18 \mathrm{GLY}$ $+0.14 \mathrm{CAR}-0.08 \mathrm{CASXCAR}$

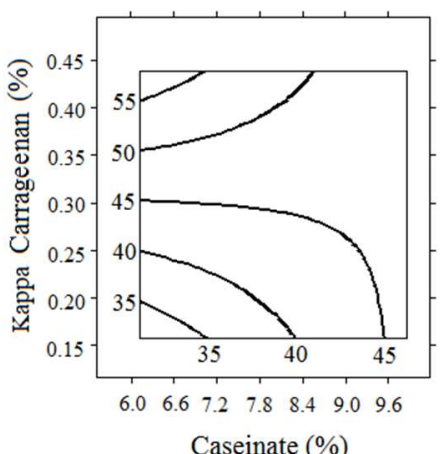

ELONG $(\%)=50.33-1.46 \mathrm{CAS}+11.15 \mathrm{GLYL}$ +8.44 CAR -3.96 CASXCAR

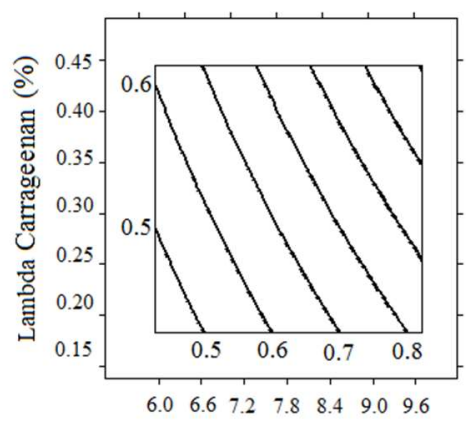

Caseinate $(\%)$

TS $\left(\mathrm{N} / \mathrm{mm}^{2}\right)=0.74+0.23 \mathrm{CAS}-0.35 \mathrm{GLY}$ $+0.12 \mathrm{CAR}+0.03$ CASXCAR

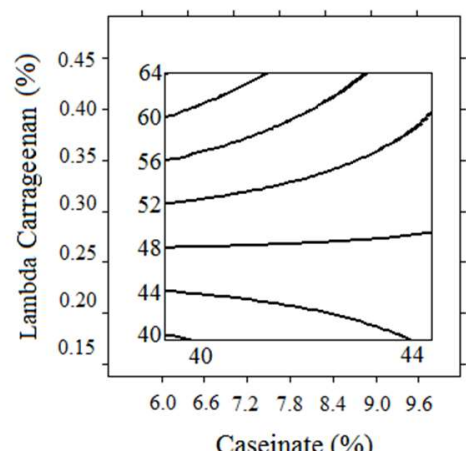

ELONG $(\%)=47.82+9.7 \mathrm{CAS}+19.27 \mathrm{GLY}$ $-1.23 \mathrm{CAR}+16.48 \mathrm{CASXCAR}$

Figure 4. Contour plot and adjusted regression equation for (a) tensile strength (TS) and (b) elongation (ELONG) for the sodium caseinate edible films elaborated with the different carrageenan type (CAS: caseinate, CAR: carrageenan, GLY: glycerol). Glycerol fixed level $=0.45 \%$.

Finally, Figure $4 \mathrm{~b}$ shown the contour plots for each carrageenan type, where at the different caseinate concentrations employed, for iota carrageenan the values remained practically constant. The caseinate $\times$ carrageenan interaction was stronger (higher parameter value and 
positive sign) in both kappa and lambda carrageenan.

Edible films prepared with polysaccharides were more flexible and more stretchable than the films prepared without them (Fabra et al., 2008). This was the main effect observed when carrageenan concentration increased. In case of iota-carrageenan, more intensive adsorption of helical parts of carrageenan chains on casein and the formation of "bridges" between caseins can be assumed, forming a more intensive network (Langendorff et al., 1999, 2000), increasing interaction at higher carrageenan concentration (Cěrníková et al., 2008). Glycerol had a negative

\section{CONCLUSIONS}

The properties of caseinate edible films were modified by the carrageenan type regarding to their conformation, where at the experimental conditions employed resulted in a strong interaction of iota and kappa carrageenan, decreasing both solubility and water vapor permeability. The use of lambda carrageenan in edible film formulation resulted in more soluble and permeably film, with a concomitantly both effect on tensile strength, but increased the elongation capacity of edible films. In caseinate films, increasing the glycerol content of films made them weaker but more stretchable (Folegatti et al., 1998; Schou et al., 2005). An edible film with good barrier properties could be inefficient if its mechanical properties not allow maintaining its integrity during the film handling. Puncture force and elasticity modulus, besides tension strain and percent of elongation, express the maximum stress developed by the film under extension test, whereas the elongation represents the film extensibility (Chiralt et al., 2012).

less rigid and more elastic structure. The edible film formulation was optimized to $8.0 \%$ of caseinate, $0.4 \%$ of carrageenan (irrespectively of the type) and $0.3 \%$ of glycerol. This implies that although lambda carrageenan showed a better functionality in caseinate edible films, iota and kappa carrageenan can be employed as well in edible film elaboration.

\section{REFERENCES}

1. Barbosa-Cánovas, G.V. (2012). Películas y recubrimientos comestibles en contexto con otras tecnologías novedosas de conservación y procesado de alimentos. In: Olivas Orozco, G.I., González-Aguilar, G.A., Martín-Belloso, O. \& Soliva-Fortuny, R. (Ed.). Películas y Recubrimientos Comestibles: Propiedades y Aplicaciones en Alimentos. Mexico City: AM Editores, pp. 13-20.

2. Benbettaïeb, N., Gay, J.P., Karbowiak, T., Debeaufort, F. (2016). Tuning the functional properties of polysaccharide-protein bio-based edible films by chemical, enzymatic, and physical cross-linking. Comprehensive review in Food Science and Food Safety, 15: 739-752.

3. Campos, C.A., Gerschenson, L.N. \& Flores, S.K. (2011). Development of edible films and coatings with microbial activity. Food and Bioprocess Technology, 4(6): 849-875.

4. Cazón, P., Velázquez, G., Ramírez, J.A., Vázquez, M. (2017). Polysaccharide-based films and coatings for food packaging: A review. Food Hydrocolloids, 68: 136-148.

5. Cěrníková, M., Buňkaa, F., Pavlínek, V., Brězina, P., Hrabě, J. \& Valásěka, P. (2008). Effect of carrageenan type on viscoelastic properties of processed cheese. Food Hydrocolloids, 22: 1054-1061.

6. Chiralt, A., Fabra, M.J. \& Sánchez-González, L. (2012). Propiedades de las películas comestibles. In: Olivas Orozco, G.I., González-Aguilar, G.A., Martín-Belloso, O. \& Soliva-Fortuny, R. (Ed.). Películas y Recubrimientos Comestibles: Propiedades y Aplicaciones en Alimentos. Mexico City: AM Editores, pp. 2157.

7. Chiralt, A., González-Martínez, C., Vargas, M., Atarés, L. (2018). Edible films and coatings from proteins. In: Yada, R.Y. (Ed.). Proteins in Food Processing, 2nd edition. Cambridge: Woodhead Publishing, pp 477500.

8. Chevalier, E., Assezat, G., Prochazka, F. \& Oulahal. N. (2018). Development and characterization of a novel edible extruded sheet based on different casein sources and influence of the glycerol concentration. Food Hydrocolloids, 75: 182-191.

9. Corredig, M., Sharafbafi, N. \& Kristo, E. (2011). Polysaccharide-protein interactions in dairy matrices, control and design of structures. Food Hydrocolloids, 25(8): 1833-1841.

10. Cuq, B., Gontard, N. \& Guilbert, S. (1995). Edible films and coating as active layers. In: Rooney, M.L (Ed.). Active Food Packaging. New York: Springer, pp. 111-142. 
11. Dalgleish, D.A. \& Morris, E.R. (1998). Interactions between carrageenans and casein micelles: electrophoretic and hydrodynamic properties of the particles. Food Hydrocolloids, 2(4): 311-320.

12. Dickinson, E. (1998). Stability and rheological implications of electrostatic milk protein-polysaccharide interactions. Trends in Food Science and Technology, 9(10): 347-354.

13. Dyshlyuk, L., Babich, O., Belova, D. \& Prosekov, A. (2017). Comparative analysis of physical and chemical properties of biodegradable edible films of various compositions. Journal of Food Process Engineering, 40(1): e12331.

14. Fabra, M.J., Talens, P. \& Chiralt, A. (2008). Effect of alginate and $\lambda$-carrageenan on tensile properties and water vapour permeability of sodium caseinate-lipid based films. Carbohydrate Polymers, 74(3): 419-426.

15. Farhan, A. \& Hani, N.M. (2017). Characterization of edible packaging films based on semi-refined kappacarrageenan plasticized with glycerol and sorbitol. Food Hydrocolloids, 64: 48-58.

16. Folegatti, M.I.S., Antunes, A.J. \& Marcondes, J.A. (1998). Mechanical and permeability properties of milk protein films. Brazilian Archives of Biology and Technology, 41(3). DOI: 10.1590/S151689131998000300008 .

17. Frinault, A., Gallant, D.J., Bouchet, B. \& Dumont, J.P. (2006). Preparation of casein films by a modified wet spinning process. Journal of Food Science, 62(4): 744-747.

18. Gennadios, A., Weller, C.L. \& Testin, R.F. (1993). Modification of physical and barrier properties of edible wheat gluten-based films. Cereal Chemistry, 70: 426-429.

19. Gornall, A.G., Bardawill, C.J. \& David, M.M. (1949). Determination of serum proteins by means of the biuret reaction. Journal of Biological Chemistry, 177(2): 751-766.

20. Gu, Y.S., Decker, E.A. \& Mcclements, D.J. (2005). Influence of pH and carrageenan type on properties of $\beta$-lactoglobulin stabilized oil-in-water emulsions. Food Hydrocolloids, 19(1): 83-91.

21. Hemar, Y., Hall, C.E., Munro, P.A. \& Singh, H. (2002). Small and large deformation rheology and microstructure of $\kappa$-carrageenan gels containing commercial milk protein products. International Dairy Journal, 12(4): 371-381.

22. Jangchud, A. \& Chinnan, M.S. (1999). Peanut protein film as affected by drying temperature and $\mathrm{pH}$ of film forming solution. Journal of Food Science, 64(1): 153-157.

23. Keogh, M.K., Lainé, K.I. \& O'connor, J.F. (1996). Rheology of sodium caseinate-carrageenan mixtures. Journal of Texture Studies, 26(6): 635-652.

24. Langendorff, V., Cuvelier, G., Launay, B., Michon, C., Parker, A. \& De Kruif, C.G. (1999). Casein micelle/iota carrageenan interactions in milk: influence of temperature. Food Hydrocolloids, 13(3): 211218.

25. Langendorff, V., Cuvilier, G., Michon, C., Launay, B., Parker, A. \& De Kruif, C.G. (2000). Effects of carrageenan type on the behaviour of carrageenan/milk mixtures. Food Hydrocolloids, 14(4): 273-280.

26. Montgomery, D.C. \& Runger, G.C. (2003). Applied Statistics and Probability for Engineers, 3rd ed. New York: John Wiley \& Sons, pp. 559-570.

27. Nilsson, S. \& Piculell, L. (1989). Helix-coil transitions of ionic polysaccharides analyzed within the Poisson-Boltzmann cell model. 2. Effects of salt concentration on the thermal transition. Macromolecules, 22(7): 3011-3017.

28. Pereda, M., Amica, G. \& Marcovich, N. (2012). Development and characterization of edible chitosan/olive oil emulsion films. Carbohydrate Polymers, 87(2): 1318-1325.

29. Pérez-Gago, M.B. (2012). Películas comestibles compuestas a base de hidrocoloides y lípidos. In: Olivas Orozco, G.I., González-Aguilar, G.A., Martín-Belloso, O. \& Soliva-Fortuny, R. (Ed.). Películas y Recubrimientos Comestibles: Propiedades y Aplicaciones en Alimentos. Mexico City: AM Editores, pp. 219-241.

30. Sadeghi, F., Kadkhodaeea, R., Ehemadzadeh, B. \& Phillips, G.O. (2018). Phase behavior, rheological characteristics and microstructure of sodium caseinate-Persian gum system. Carbohydrate Polymers, 179(1): 71-78.

31. Schou, M., Longares, A., Montesinos-Herrero, C., Monahan, F.J., O'riordan, D. \& O’sullivan, M. (2005). Properties of edible sodium caseinate films and their application as food wrapping. LWT-Food Science and Technology, 38(6): 605-610.

32. Singh, H., Tamehana, M., Hemar, Y. \& Munro, P.A. (2003). Interfacial compositions, microstuctures and properties of oil-in-water emulsions formed with mixtures of milk proteins and $\kappa$-carrageenan: 1 . Sodium caseinate. Food Hydrocolloids, 17(4): 539-548.

33. Snoeren, T.H.M., Paynes, T.A.J., Jeunink, J. \& Both, P. (1975). Electrostatic interaction between $\kappa-$ carrageenan and $\kappa$-casein. Milchwissenschaft, 30: 391-396.

34. Sobral, P.J.A., Menegalli, F.C., Hubinger, M.D. \& Roques, M.A. (2001). Mechanical, water vapor barrier and thermal properties of gelatin based edible films. Food Hydrocolloids, 15(4-6): 423-432.

35. Soliva-Fortuny, R., Rojas-Graü, M.A. \& Martín-Belloso, O. (2012). Polysaccharide coatings. In: Baldwin, E.A., Hagenmaier, R. \& Bai, J. (Ed.). Edible coatings and films to improve food quality, $2^{\text {nd }}$ ed. Boca Raton: CRC Press, pp 103-136. 
36. Spagnuolo, P.A., Dalgleish, D.G., Goff, H.D. \& Morris, E.R. (2005). Kappa-carrageenan interactions in systems containing casein micelles and polysaccharide stabilizers. Food Hydrocolloids, 19(3): 371-377.

37. Wu, Y., Weller, C.L., Hamouz, F., Cuppett, S.L. \& Schnepf, M. (2002). Development and application of multicomponent edible coatings and films: A review. Advances in Food and Nutrition Research, 44(1): 347-394.

38. Ye, A. (2008). Complexation between milk proteins and polysaccharides via electrostatic interaction: principles and applications -A review. International Journal of Food Science and Technology, 43(3): 406415.

39. Zaritzky, N. (2011). Edible Coatings to Improve Food Quality and Safety. In: Aguilera, J.M., BarbosaCánovas, G.V. Simpson, R., Welti-Chanes, J. \& Bermúdez-Aguirre, D. (Ed.). Food Engineering Interfaces. New York: Springer, pp. 631-659. 